UDC 338

DOI: https://doi.org/10.32782/2413-9971/2021-36-28

\author{
Tsapko-Piddubna Olga \\ Candidate of Economic Sciences, \\ Senior Lecturer at Department of International Economic Analysis and Finance \\ Ivan Franko National University of Lviv \\ ORCID: https://orcid.org/0000-0002-7233-6019
}

Цапко-Піддубна О. I.

кандидат економічних наук, доцент кафедри міжнародного економічного аналізу та фінансів Львівського національного університету імені Івана Франка

\title{
INCLUSIVE GROWTH AND DEVELOPMENT PATTERNS OF CENTRAL AND EASTERN EUROPEAN COUNTRIES
}

Summary. The primary intension behind this study is to analyse and compare the patterns of inclusive growth and development across economies of Central and Eastern Europe based on a performance metric developed by the World Economic Forum. The current state of growth and inequality is analyzed through pillars of 1) growth and development; 2) inclusion; and 3 ) intergenerational equity and sustainability. The EU and Norway, the most inclusive country in 2017, were included into the study as a benchmark. The main findings suggest that the Czech and Slovak Republic are the best performing among CEE countries in inclusive growth and development patterns. On the contrary, Ukraine, Moldova, and Russian Federation are the worst. These countries have not transformed their economic growth into social inclusion. In order to improve the inclusiveness of economic growth, it is recommended to promote policies that would increase human economic opportunities and productive employment, and consequently, both equality and economic well-being of CEE economies.

Key words: inclusive growth and development, income and wealth inequality, economic opportunity, productive employment.

Introduction. For decades economic growth has long been a top policy goal for countries around the world. Economists and policymakers have focused on increasing economic growth and accelerating cross-country convergence, while paying less attention to growing inequality of income, wealth, and opportunity. However, over the past several years, a worldwide consensus has emerged on the need for more socially inclusive approach to generate economic growth. This approach pays attention to detrimental macroeconomic effects of income and wealth inequality, inequality of opportunity and poverty. Considering this, inclusive growth - an economic growth that is distributed fairly across society and creates opportunities for all - has become a central concern in the development literature and in policymaking in many countries.

The transition economies of Central and Eastern European countries (CEE countries - the Czech Republic, Estonia, Hungary, Latvia, Lithuania, Moldova, Poland, Romania, the Russian Federation, the Slovak Republic, and Ukraine) with the abandonment of communist economic practices started the reformation process towards market economy intending for future sustained economic growth, equal opportunities, and prosperity for all their citizens. But the transition reforms, like privatization, trade and financial liberalization/deregulation not only led to development and growth, but also, they have contributed to the redistribution of income and wealth in societies breeding the stronger economic and political influence of more newly created affluent elites.

Thus, the purpose of this study is to evaluate and compare the inclusiveness of growth and development of CEE economies and to define the potential to its improvement.

Theoretical background and methodology. The concept of inclusive growth has been lately developed in times of economic and social instability, with understanding that lowering inequality of income, wealth, and opportunity is vital to long-term sustained economic growth. Besides, economists highlight that policies driven by an exclusive growth focus can set back inclusion and vice versa, high and persistent inequality can undermine the sustainability of growth itself (IMF, 2017). According to present approach, growth and inequality reduction are instrumental to each other and they are a by-product of a prudent policymaking.

A Nobel laureate J. Stiglits (2016) defends point of view that rules do matter as they determine how fast the economy grow, and who shares in the benefits of that prosperity. He argues that we do not have to sacrifice sustained economic growth for the sake of equality.

With understanding that economic growth is not the only priority of any economic policy, the inclusive growth and development concept have been taking ground around the world. The World Economic Forum (WEF, 2017; 2018), the International Monetary Fund (2017), and the World Bank $(2008$; 2021) considerably contributed to the development of this concept.

Considerable attention to the interaction of economic growth, poverty, inequality of income, wealth and opportunities is devoted in the studies of the other Nobel laureate - M. Spence (2008), as well as in the studies of E. Ianchovichina (2009), S. Klasen (2010), J. Ostri (2014), A. Berg (2011), G. Grimalda and Meschi E. (2008) and others.

International organizations and scholars have been working not only on the concept of inclusive growth and development. They also have made great contribution to practical aspects of its evaluation. For example, WEF suggests a performance metric that evaluates inclusive socio-economic progress and enables to consider the distributional concerns. This performance metric of inclusive growth is represented by number of indicators Key Performance Indicators - which independently can evaluate progress in different spheres that are relevant to inclusive growth. At the same time values of these indicators are taken to calculate a composite index - the Inclusive Development Index (IDI), the score of which may vary from 1 to 7 (with 1 representing the worst case, and 7 - the best). 
As the purpose of this study is to evaluate and compare the inclusiveness of CEE countries' socio-economic progress, these Key Performance Indicators of inclusive growth and development are used to evaluate countries' growth and development; inclusion; intergenerational equity and sustainability aspects. A comparative analysis of CEE economies based on them allows to detect these countries' growth pattern and their potential to improve social inclusiveness. Data for the EU-28 and Norway (the most inclusive country in 2018) are added into the analysis as the benchmark for CEE economies.

Results and discussion. The following part of this study is devoted to evaluation and comparison of CEE countries inclusive growth and development patterns based on WEF Key Performance Indicators.

Most CEE economies are quite inclusive, and their IDI scores vary with a tendency of higher ones belonging to the EU members and lower - to non-EU countries (Figure 1).

Among CEE economies the Czech and Slovak Republics have the highest values of IDI. These countries succeeded in making their growth processes more socially inclusive as they have significantly higher scores in IDI ranking than based on GDP per capita among advanced economies (Table 1). Estonia, Romania, and Moldova follow inclusive tendency of growth and development, too. On the contrary, the Russian Federation and Ukraine have significantly lower rankings in IDI than in GDP per capita, suggesting that their economic growth has not transformed as well into social inclusion. Moreover, Ukrainian IDI score is half lower of conceptually possible score and is the lowest among CEE economies.

Comparing with the EU average IDI score, only Czech score is higher among CEE economies. There still exists significant potential for all the rest countries to reach EU level and another great challenge for all analysed CEE countries to move towards the level of Norway.

Analysing in detail the Norwegian and CEE countries' inclusiveness of growth, in particular IDI pillars (growth and development; inclusion; and intergenerational equity and sustainability), it is observed that in Norway all three pillars have almost equal positive influence on a composite index IDI, while in CEE countries the influence is unequal and differs among them. For the majority of CEE countries, the most significant positive influence belongs to intergenerational equity and sustainability pillar and for Ukraine, Hungary, and Slovak Republic - to inclusion one (Figure 2).

The influence of growth and development pillar is the least significant in all CEE countries (except for Estonia). So, there is a potential and a need to improve economic component of development because sustained positive rates of growth and labour productivity are as vital for inclusive growth as an equal income and wealth distribution. Long-term, sustained economic growth with high rates is necessary to reduce poverty and growing productive employment is necessary to reduce inequality. It is worth mentioning that over the past

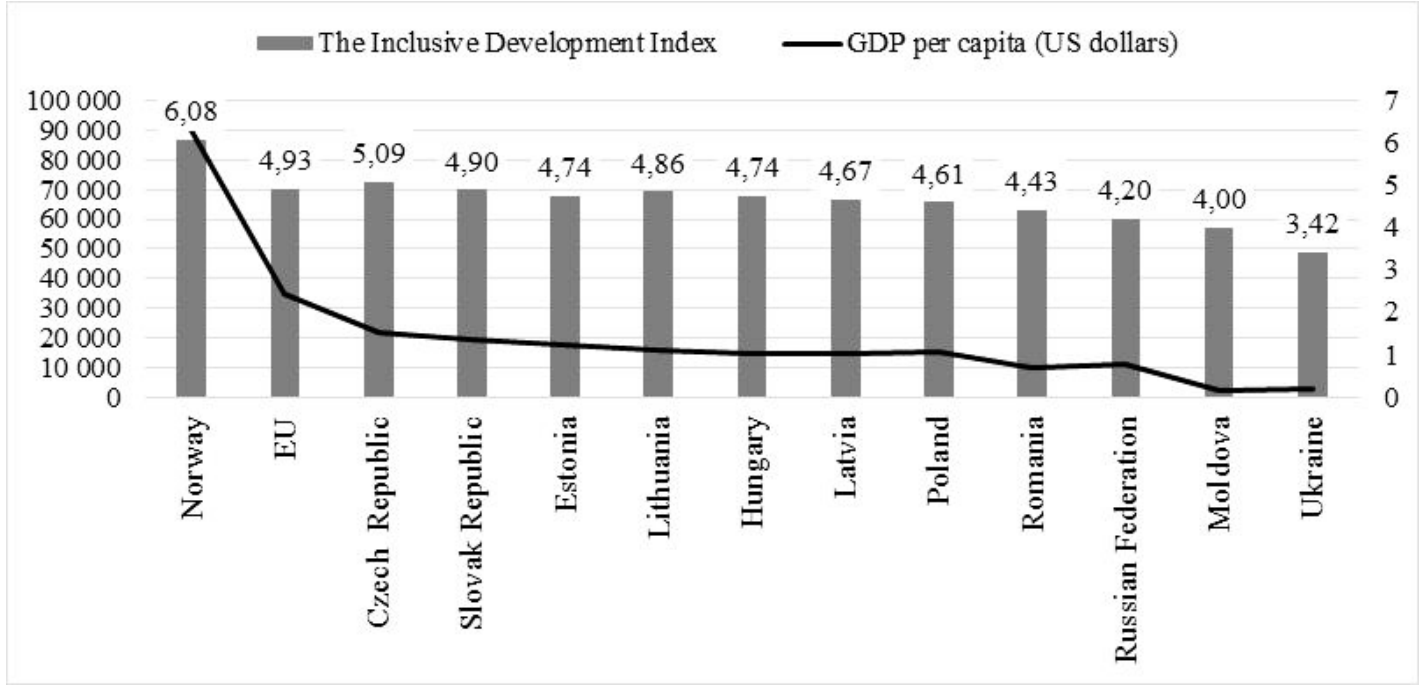

Figure 1. Comparative Performance of IDI versus GDP per capita 2018. Source: World Economic Forum (2018); World Development Indicators Database (2018)

Table 1

Comparative performance of IDI ranking versus GDP per capita ranking for Norway and CEE countries 2018

\begin{tabular}{|c|c|c|c|c|c|c|c|c|c|c|c|c|}
\hline & \multirow{2}{*}{\multicolumn{3}{|c|}{ Advanced Economies }} & \multicolumn{9}{|c|}{ Emerging Economies } \\
\hline & & & & \multicolumn{6}{|c|}{ Upper-Middle Income } & \multicolumn{3}{|c|}{ Lower-Middle Income } \\
\hline Rank & ż & 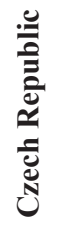 & 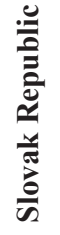 & & 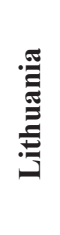 & 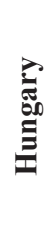 & 莡 & 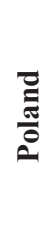 & 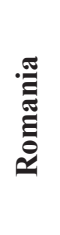 & 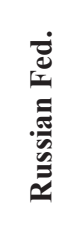 & $\frac{\sqrt[\pi]{2}}{\frac{0}{0}}$ & \\
\hline IDI & 1 & 15 & 20 & 22 & 1 & 2 & 4 & 5 & 10 & 19 & 31 & 49 \\
\hline GDP per capita & 2 & 28 & 29 & 30 & 1 & 4 & 5 & 3 & 15 & 9 & 49 & 43 \\
\hline
\end{tabular}

Source: World Economic Forum (2018) 


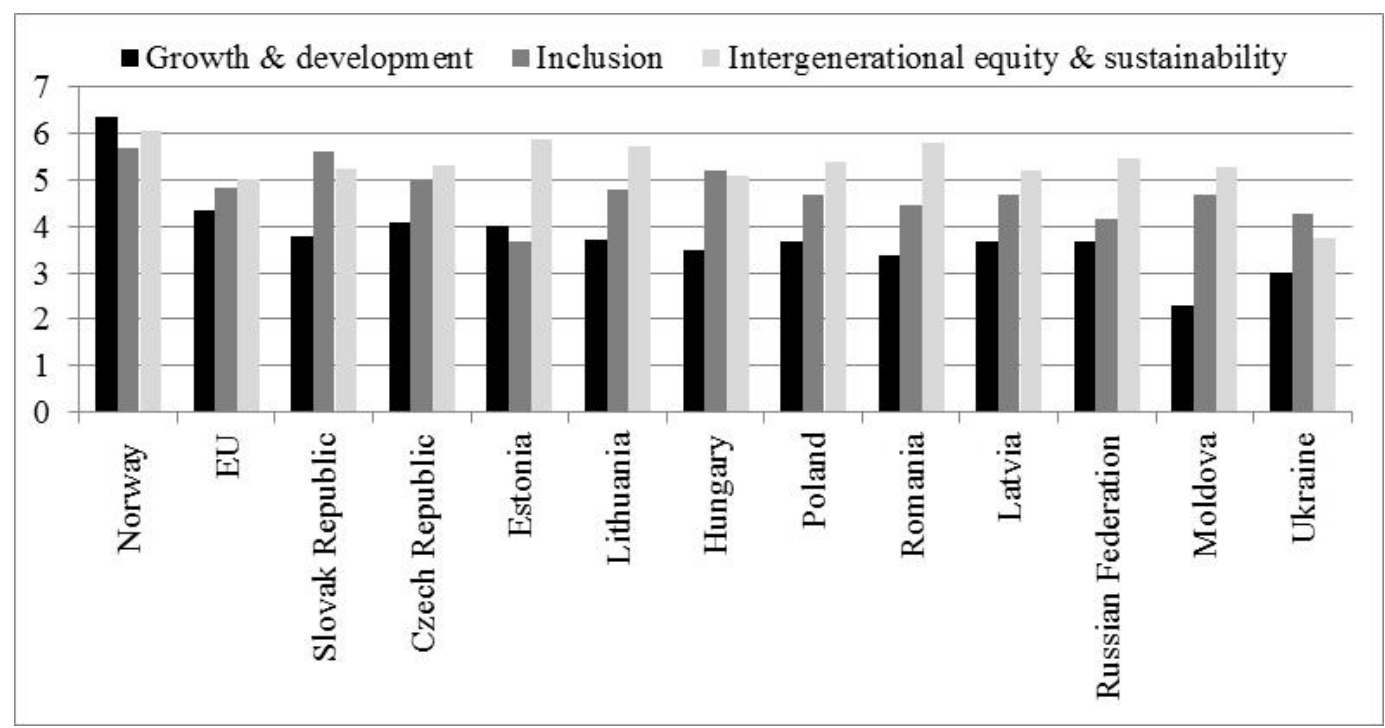

Figure 2. National Key Performance Indicators for CEE countries

Source: World Economic Forum (2018)

several years CEE countries - the EU members have been performing constantly well on growth and development pillar.

For better understanding of distributional processes in CEE economies, values of inclusion pillar indicators (net income Gini, wealth Gini and median income) are analysed. As it is shown on Figure 3, the values of net income GINI are quite low which means that the net distribution of income (that is, post-tax, post-transfers) among individuals or households within each economy is quite equal. However, in many CEE countries incomes are equally low. For example, in Norway median income is 63.8 (USD); in EU - 31.54 (USD); and in all CEE countries it is lower than 26 (USD). The highest value of median income belongs to Latvia and the lowest to Moldova. Romania and Ukraine are not far ahead (Figure 3).

The distribution of wealth (financial assets and real estate minus debt) is more unequal than of income within each $\mathrm{CEE}$ country (Figure 3 ). It reflects, among many other factors, the cumulative effect of persistent income inequality, movements in asset prices, as well as the lower propensity to save by middle- and lower-income workers, and a lower propensity to consume by the rich.

Ukraine has one of the highest levels of wealth inequality among developing countries. Its wealth Gini equals 90.1. In Norway (80.5) and the Russian Federation (82.6) the wealth is also distributed quite unequal. The difference between Norway and CEE economies, like Russia and Ukraine, is that in the latter countries the wealth has been accumulated over the shorter time period and its inequality of distribution is partly due to low propensity to save by middle- and lowerincome workers. For example, in Norway adjusted net savings are equal to $20.6 \%$ of GNI, by contrast in Russia and Ukraine the values of this indicator are $9.3 \%$ and $1 \%$ respectively (WEF, 2017). Moreover, in Russia and Ukraine during the

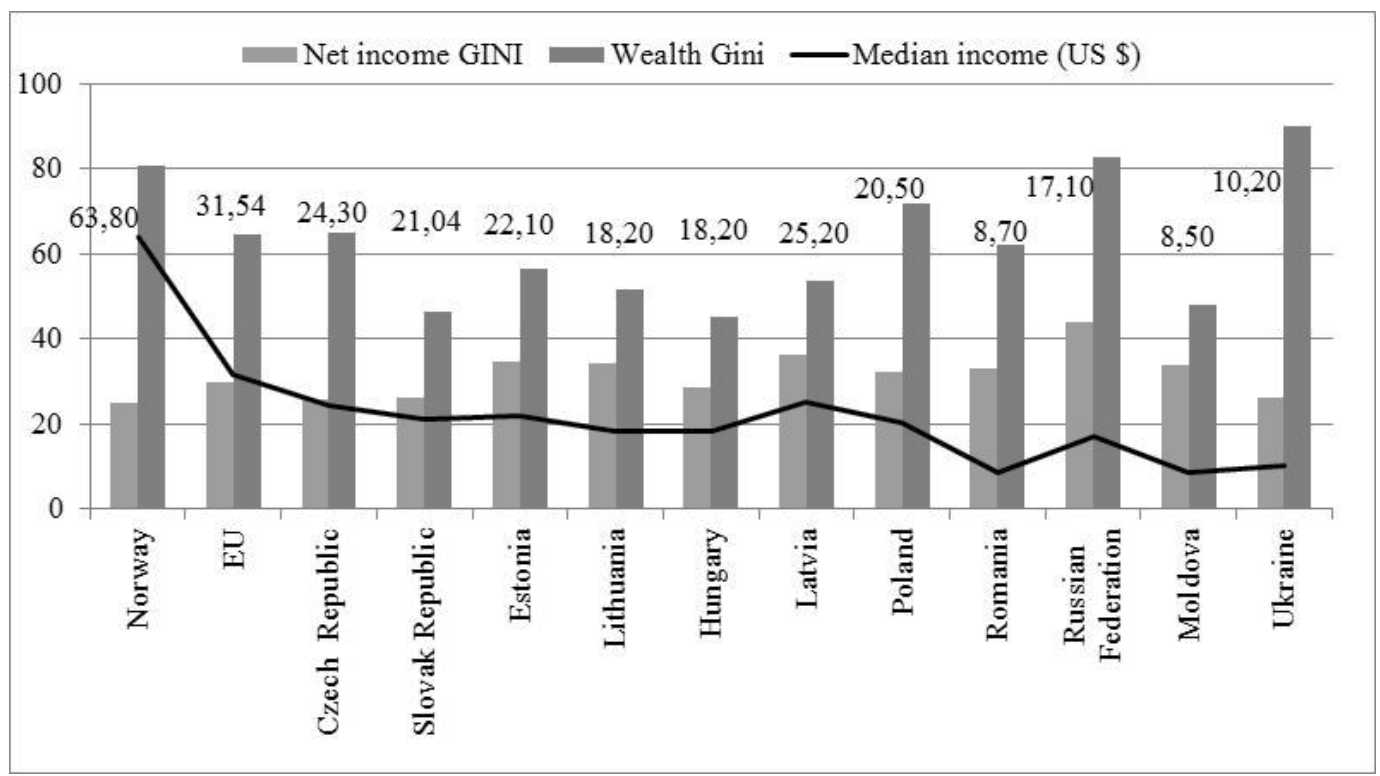

Figure 3. Income and wealth distribution 2018

Source: World Economic Forum (2018); Credit Suisse (2017) 


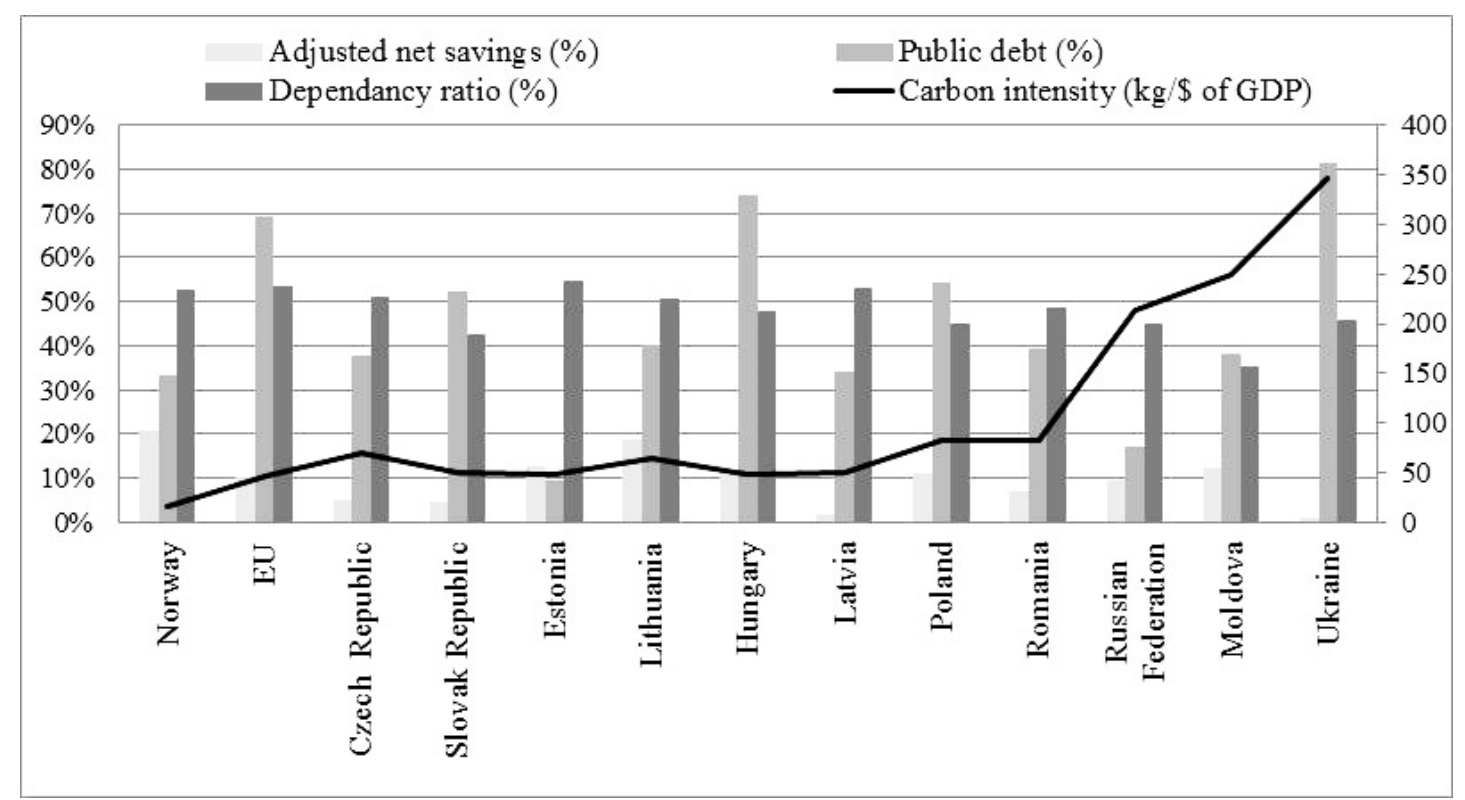

Figure 4. The intergenerational equity and sustainability. Source: World Economic Forum (2018)

transition, elites-oligarchs accumulated their wealth as a result of redistribution of state ownership and due to the extraordinary gains of having an influence on state decisionmaking process.

The intergenerational equity and sustainability pillar evaluates whether growth and gains in living standards are socially inclusive and are generated in a manner that is sustainable for younger and future generations.

Most CEE countries perform well in this pillar, except for Ukraine (Figure 2 and Figure 4): its economy is energy inefficient and carbon intensive; it has constantly growing public debt, which is difficult to maintain; and its adjusted net savings are at low level.

In order to increase the synergy between the growth of the national economy and broad-based improvements in living standards, it is advisable for CEE countries to develop policies that promote equality of opportunities. In particular, to promote: an equality in access to markets, resources, as well as to well-regulated and fair business environment; an equality in development and realization of human potential, regardless of socio-economic origin, gender, place of birth and ethnic roots. This can be ensured by efficient governmental policy in spheres of education, health care and infrastructure development that will expand access of all members of society to the process of economic growth apart from redistribution of economic results.

Productive employment is the other core feature of socio-inclusive economic growth. It is at the same time a driver of economic growth and a necessary condition for reducing economic inequality. In order to increase productive employment, the governmental policy should stimulate the development of productive sectors; train and retrain employees from less productive sectors and unemployed (within the concept of inclusive growth, each person is valuable and unique to society and has a state-guaranteed right to meet their needs). Besides, like in a stakeholder capitalism, there is a clear need to defend the interests of workers, apart from the interests of corporations or top managers. This might be done by strengthening the role of independent and reputable trade unions.

Therefore, an inclusive economic growth strategy of CEE countries should further focus on:

- equality of economic and human opportunities;

- productive employment;

- interaction of market forces and government policies (social, fiscal, monetary; labour market policy, etc.)

- long-term perspective.

Conclusions. Economic growth is a necessary but not a sufficient condition for generating inclusive socio-economic progress and broad-based improvements in living standards. CEE countries further development should go in line with inclusive growth and development theory by supporting economic growth, inequality reduction, and by promoting economic opportunities with prudent policymaking.

The EU membership obviously supports such the inclusive growth policymaking as the EU members - CEE economies perform better in IDI scores and other Key Performance Indicators than non-EU countries. The Czech and Slovak Republics are the best performing economies among CEE countries in inclusive growth and development patterns. On the contrary Ukraine, Moldova, and the Russian Federation are the worst. These countries' economic growth has not been transformed well into social inclusion.

Therefore, basic principles of inclusive growth concept, as economic equality (equality in income, wealth, and opportunities) and an increase in productive employment, altogether will contribute to sustainable long-term economic growth of all CEE economies.

\section{References:}

1. Stiglitz J.E. (2016). Rewriting the Rules of the American Economy: An Agenda for Growth and Shared Prosperity. Roosevelt Institute, no. 1, p.115. Available at: https://community-wealth.org/sites/clone.community-wealth.org/files/downloads/report-stiglitz.pdf.

2. World Economic Forum (2017). The Inclusive Growth and Development Report 2017. WEF working paper, no. 1, p. 75. Available at: http://www3.weforum.org/docs/WEF_Forum_IncGrwth_2017.pdf. 
3. World Economic Forum (2018). The Inclusive Development Index 2018 Summary and Data Highlights. WEF working paper, pp. 1-14. Available at: http://www3. weforum.org/docs/WEF_Forum_IncGrwth_2018.pdf.

4. International Monetary Fund (2017). Fostering Inclusive Growth. G-20 Leaders' Summit, July 7-8, 2017. IMF working paper, pp. 1-36. Available at: https://www.imf.org /external/np/g20/pdf/2017/062617.pdf.

5. World Bank. World Development Indicators Database (2021). Available at: http://databank.worldbank.org/data/reports.aspx? source $=$ world-development-indicators.

6. Spence M. (2008) The Growth Report : Strategies for Sustained Growth and Inclusive Development. World Bank.

7. Ianchovichina E. (2009) Inclusive Growth Analytics: Framework and Application / E. Ianchovichina, S. Lundstrom. World Bank Policy Research Working Paper, no. 4851.

8. Klasen S. (2010) Measuring and Monitoring Inclusive Growth: Multiple Definitions, Open Questions, and Some Constructive Proposals. Asian Development Bank Sustainable Development Working Paper Series, no. 12.

9. Ostry A. Berg, Tsangarides C. (2014) IMF Staff Discussion Note. Available at: https://www.imf.org/external/pubs/ft/sdn/2014/ sdn1402.pdf.

10. Berg A. (2011) Equality and Efficiency: Is there a trade-off between the two or do they go hand in hand? / A. Berg, J. Ostry. Finance and Development, no. 48(3), pp. 12-15.

11. Grimalda G., Meschi E. (2008) Accounting for inequality in transition economies: an empirical assessment of globalisation, institutional reforms, and regionalization. CSGR Working Paper, no. 243/08, pp. 1-47.

\section{ТЕНДЕНЦІЇ ІНКЛЮЗИВНОСТІ ЕКОНОМІЧНОГО ЗРОСТАННЯ ТА РОЗВИТКУ КРАЇН ЦЕНТРАЛЬНОЇ ТА СХІДНОЇ ЄВРОПИ}

Анотація. У науковій літературі та у творенні політики розвитку інклюзивне економічне зростання вважають основою стійкого соціально-економічного розвитку країни, адже у зазначеній концепції економічного зростання увагу зміщено з темпів зростання ВВП на користь розподілу багатства між населенням, його економічних можливостей. Так, економічне зростання $є$ інклюзивним, якщо зосереджене на широко розповсюдженому підвищенні добробуту населення та розширенні його економічних можливостей.

Зважаючи на наукову актуальність теми та практичну необхідність переходу країн до стійкого соціальноекономічного розвитку, у статті здійснено порівняльний аналіз інклюзивності економічного зростання та розвитку країн Центральної та Східної Свропи. Ці країни, у тім числі України, під час переходу до ринкових умов господарювання намагалися максимізувати економічне зростання, разом з тим різною мірою зосереджувались на широко розповсюдженому підвищенні добробуту населення та розширенні його економічних можливостей.

Серед країн Центральної та Східної Європи, Чехії та Словаччині найкраще вдалось змістити акценти 3 темпів економічного зростання на користь соціально-економічної інклюзивності. Загалом, варто відзначити, що економічний розвиток країн Центральної та Східної Європи - членів СС є більш інклюзивним. На противагу, для Російської Федерації, Молдови та України спостерігаємо негативні тенденції в цьому аспекті. За трьома групами показників індексу інклюзивного розвитку, розроблених міжнародною організацією - Світовим економічним форумом, для України спостерігаємо порівняно вкрай низьку результативність.

3 метою покращення інклюзивності економічного зростання, ми рекомендуємо політику, яка сприяла б збільшенню людських економічних можливостей (зокрема, політику у сферах освіти, охорони здоров'я та розвитку інфраструктури) та стимулювала повну та продуктивну зайнятість, коли кожен член суспільства долучений як до процесу творення ВВП (відповідно до принципу рівності економічних можливостей), так і до справедливого розподілу результатів економічної діяльності.

Ключові слова: інклюзивне зростання та розвиток, нерівність доходів та багатства, економічні можливості, продуктивна зайнятість.

\section{ТЕНДЕНЦИИ ИНКЛЮЗИВНОСТИ ЭКОНОМИЧЕСКОГО РОСТА И РАЗВИТИЯ СТРАН ЦЕНТРАЛЬНОЙ И ВОСТОЧНОЙ ЕВРОПЫ}

Аннотация. В научной литературе и в создании политики развития инклюзивное экономический рост считают основой устойчивого социально-экономического развития страны, ведь в указанной концепции экономического роста внимание смещены с темпов роста ВВП в пользу распределения богатства между населением, его экономических возможностей. Так, экономический рост является инклюзивным, если сосредоточен на широко распространенном повышении благосостояния населения и расширении его экономических возможностей.

Учитывая научную актуальность темы и практическую необходимость перехода стран к устойчивому социальноэкономического развитию, в статье осуществлен сравнительный анализ инклюзивности экономического роста стран Центральной и Восточной Европы. Эти страны, в том числе Украина, при переходе к рыночным условиям хозяйствования пытались максимизировать экономический рост, вместе с тем в разной степени были сосредоточены на широко распространенном повышении благосостояния населения и расширении его экономических возможностей.

Среди стран Центральной и Восточной Европы, Чехии и Словакии лучше удалось сместить акценты с темпов экономического роста в пользу социально-экономической инклюзивности. Стоит отметить, что экономическое развитие стран Центральной и Восточной Европы - членов ЕС является более инклюзивным. Напротив, для Российской Федерации, Молдовы и Украины наблюдаем негативные тенденции в этом аспекте. По трем группам показателей индекса инклюзивного развития, разработанных международной организацией - Всемирным экономическим форумом, для Украины наблюдаем сравнительно крайне низкую результативность.

С целью улучшения инклюзивности экономического роста, рекомендуем политику, которая способствовала бы увеличению человеческих экономических возможностей (в частности, политику в сферах образования, здравоохранения и развития инфраструктуры) и стимулировала полную и продуктивную занятость, когда каждый член общества приобщен как к процессу создания ВВП (в соответствии с принципом равенства экономических возможностей), так и к справедливому распределению результатов экономической деятельности.

Ключевые слова: инклюзивный рост и развитие, неравенство доходов и богатства, экономические возможности, продуктивная занятость. 